\title{
AFLATOXIN B1 LEVEL IN RELATION TO CHILD'S FEEDING AND GROWTH
}

\author{
$\mathcal{B Y}$ \\ Doaa A. El Morsi, Samira Shabaan, Abdelhamid M. Abdelhamid*, \\ Ahmed I. Mehrim* and Basma O. Shouman** \\ Departments of Forensic Medicine and Clinical Toxicology-Faculty of Medicine; Animal Production*, \\ Faculty of Agriculture and Paediatrics, Mansoura University Children Hospital** \\ Mansoura University, Egypt
}

\begin{abstract}
Aflatoxins are a group of toxins produced in foods contaminated by the molds Aspergillus flavus and Aspergillus parasiticus and have been implicated as a causative agent in human hepatic and extrahepatic carcinogenesis. This study was conducted to establish the influence of sociological factors, breast feeding and weaning on aflatoxin exposure in children as well as to determine the effect of aflatoxin exposure on children's growth. Aflatoxin BI (AFB1) in blood was used as a biomarker for exposure to aflatoxin. Thin Layer Chromatography (TLC) was used for the analysis of AFB1 in blood samples from 46 mothers and their children after taking informed consent from mothers. The mean \pm SE level of AFB1 of positive children is $66.735 \pm 16.3757 \mathrm{ppb}$. While the mean \pm SE level of AFB1 of mothers of positive children is $(68.0131 \pm 11.5195 \mathrm{ppb})$. AFB1 level was not affected by child's age, sex, residence (whether rural or urban), maternal age, parity, education nor occupation. AFB1 in breastfed children was significantly lower than in non-breastfed (artificially-fed, cow's milk fed or fully weaned) ones. Weight - z - score (WAZ) showed no significant difference between AFB1 negative and positive cases while height - z - score (HAZ) was significantly lower in AFB1 positive compared to AFB1 negative cases. A significant negative correlation between AFB1 concentration and their height-z-score while correlation between AFB1 concentration and WAZ was non-significant. In conclusion, this study suggests that breast feeding results in lower AFB1 exposure and that there is a strong association between aflatoxin exposure and impaired growth.
\end{abstract}

Key words: Aflatoxin Residues, Child, Weight, Height.

\section{INTRODUCTION}

A common type of fungus that can grow inside the body is a mould produces a mycotoxin called aflatoxin. The regions more affected by aflatoxins are those with tropic or subtropic climate, since the levels of humidity and temperature play an important role in fungi's growth (Duncan and Hagler, 2008; Averkieva, 2009).

Aflatoxins are a group of toxins produced in foods contaminated by the molds Aspergillus flavus and A. parasiticus 
(Zarba et al., 1992). The toxins have been implicated as causative agent in human food borne intoxication (Abdelhamid et al., 1999), as well as a causative agent in human hepatic and extrahepatic carcinogenesis (Massey et al., 1995). While a number of investigations have examined human exposures to aflatoxins from the diet, methodological constraints have inhibited extensive investigations to assess maternal to child exposure from breast milk to a major carcinogenic metabolite of AFB1, aflatoxin M1 which is the hydroxylated metabolite of AFB1 formed in liver by cytochrome p450 associated enzymes (Kamkar, 2005).

Prenatal exposure to aflatoxin produced delayed development, impaired locomotors coordination, and impaired learning ability in the offspring of rats exposed to aflatoxin during middle pregnan$\mathrm{cy}$, and the early gestational exposure appeared to produce more effects than latter exposure (Kihara et al., 2000). Its chronic symptoms include liver and kidney damage, reduced growth, anemia, bruising and immune suppression (Herman and Trigo- Stockli, 2008).

Among commonly occurring mycotoxins, AFB1 has gained immense importance due to its biological effects and widespread toxicity (Trail et al., 1995). The toxico-pathological spectrum of AFB1 is very wide encompassing different kinds of toxicities, such as: acute, chronic carcinogenicity, teratogenicity, genotoxicity and immunotoxicity. Mycotoxins cause potential threat to animal and human health in view of their teratogenicity, but the reports and literature showed that the studies in the field of mycotoxins - teratogenesis are very limited. The use of biological markers over the last 10-15 years indicated that people are chronically exposed to high levels of aflatoxins starting in utero and continuing throughout life (Montesano et al., 1997).

The presence of AFB1 in cord blood samples from pregnant women also suggested fetal exposure through transplacental transfer of the mycotoxin $(\mathrm{DeV}-$ ries et al., 1989; Denning et al., 1990; Hsieh and Hsieh, 1993; Maxwell et al., 1994; Jonsyn et al., 1995; Abdulrazzaq et al., 2004).

This study was conducted to establish the influence of sociological factors, breast feeding and weaning on aflatoxin exposure in children as well as to determine the effect of aflatoxin exposure on children's growth.

\section{SUBJECTS \& METHODS}

Subjects : Forty six children (their ages ranged from 2 months to 2.5 years), and their mothers (their ages ranged from 19 36 years), admitted to Mansoura University Children's Hospital during 18 months 
period were chosen randomly to be recruited in the study. All subjects were free from any hepatic or renal diseases as well as from any chronic illness or malnutrition that may affect growth. A questionnaire, given to the mothers of children recruited in the study, obtained information on the children age, sex, residence, feeding, weaning status and general health status. Additional data concerning maternal parity, education and occupation were collected. Children's height and weight using a spring balance (SMIC Health Scale, RGZ120, China) were measured as well as height for age Z-score (HAZ), weight for age Z-score (WAZ), and weight for height $Z$-score were calculated at the time of recruitment.

Sampling: Five ml blood sample were drown from each participant after taking the mother's consent, all blood samples were kept frozen until analysis. The qualitative and quantitative determination of AFB1 by TLC was carried out according to the method of Eppley (1968), modified by Abdelhamid (1981). The laboratory studies were undertaken in the mycotoxin laboratory of Animal Production Department, Faculty of Agriculture, Mansoura University. All chemicals and solutions used were purchased from United Co. for Chemical and Medical Preparations, Cairo, Egypt. Mycotoxin standard used was from Makor Chemicals Co., Jerusalem. The detection level is $0.5 \mathrm{ppb}$.
Blood was extracted with chloroform in a separate funnel, filtrated on anhydrous sodium sulfate and then the filtrate was evaporated under vacuum at $45^{\circ} \mathrm{C}$ till dryness using electric vacuum evaporator from Sartorius, Switzerland. The residues were dissolved in $100 \mu \mathrm{l}$ chloroform for spotting on a TLC plate against external standard. The plate was developed in toluene/acetic acid/formic acid (6/3/1, v/ $\mathrm{v} / \mathrm{v}$ ) for $45 \mathrm{~min}$, air dried, sprayed with sulfuric methanol and observed under Ultraviolet lamp at $366 \mathrm{~nm}$ for qualitative determination. For the quantitative estimation, the spots of the samples as well as of the standard were scratched separately, dissolved in similar volumes of chloroform on filter papers onto test tubes and then the optical density (OD) was measured spectrophotometrically for all extracts using the following equation:

The concentration of AFB1 (ppb) in a sample $=\mathrm{OD}$ of the standard $\mathrm{X}$ ppb of the standard / OD of a sample.

Statistical analysis: The statistical analysis of data was done by using SPSS program (statistical package for social science version 10). The description of data was done using mean \pm SE for quantitative data, frequency \& percentage for qualitative data. The analysis of data was done using Chi - square $\left(\chi^{2}\right)$ for qualitative data and independent sample t- test and Z test for quantitative data. To test the association between variables; correlation 
coefficiency test was used.

N. B. $p$ is considered significant if $\leq 0.05$ at confidence interval $95 \%$.

\section{RESULTS}

AFB1 is detected in 17 out of 46 $(36.96 \%)$ of the blood samples of children at a mean \pm SE concentration of $66.735 \pm$ 16.3757 ppb and $68.0131 \pm 11.5195 \mathrm{ppb}$ in their mothers. All the 17 children have positive AFB1 mothers. Sociodemographic data of the studied groups having negative or positive blood levels of AFB1 are shown in (Table 1 \& Charts 1 and 2). The age of children with positive aflatoxin ranges from 3 months to 1.2 years, while the age of children with negative aflatoxin ranges from 2 months to 2.5 years. AFB1 positive and negative children show no significant difference regarding their age, sex, residence, maternal age, parity, education nor occupation.

Children are classified as either breastfed (partially or wholly breastfed) 17 out of 46 and 29 out of 46 are non - breastfed; of whom 21 out of 46 are receiving artificial milk (partially or wholly artificially fed); 2 out of 46 are receiving cow's milk and 6 out of 46 are fully weaned. From the 17 breastfed children only 3 are AFB1 positive, while 14 out of 29 are non breastfed (artificially fed, cow's milk or fully weaned) children are AFB1 positive $(p=0.034)$. As regards growth parameters, weight-z-score (WAZ) shows no significant difference between AFB1 negative and positive cases $(p=0.422)$ while heightz-score (HAZ) is significantly lower in AFB1 positive compared to AFB1 negative cases $(p=0.001)$ as shown in table (2).

There is a significant positive correlation between AFB1 concentration in the children and their mothers $(p=0.0001)$, also a significant negative correlation between AFB1 concentration in the studied cases and their height-z-score $(p=0.001)$ while correlation between AFB1 concentration in the studied cases and weight-zscore is non-significant $(p=0.185)$ as shown in table (3).

\section{DISCUSSION}

Exposure of humans to aflatoxins can be determined by a combination of food analysis and food intake studies or by monitoring levels of aflatoxins in biological fluids which is a more direct and reliable indicator of actual exposure. The breast milk as a biological fluid is easily obtained during breast feeding and, very importantly, it permits the assessment of the exposure of infants to aflatoxins (El Nezami et al., 1995).

This study was conducted to establish the influence of sociological factors, breast feeding and weaning on aflatoxin exposure in children as well as to determine 
the effect of aflatoxin exposure on children's growth.

The present study demonstrated that the level of AFB1 was not affected by child's age, sex, residence whether rural or urban, maternal age, parity, education nor occupation (Table 1). Socioeconomic status might have been expected to correlate with poor food quality and higher aflatoxin level but no strong effect was observed. This was in accordance with the results of Gong et al. (2003) who found no statistically significant difference in aflatoxin level between male and female children. Similarly, they found that socioeconomic status showed no statistically significant correlation with aflatoxin level. Gong et al. (2003), demonstrated that aflatoxin levels were lowest in children age $<1$ year and increased with age up to 2-3 years old, at which point levels reached a plateau. However, this trend was not significant when adjusted for weaning and socioeconomic status. Sadeghi et al. (2009), similarly did not show significant correlation between aflatoxin M1 which is the metabolite of AFB1and postnatal age, gender, the number of children nor the number of family members.

Furthermore the present study reveals that there is a relationship between AFB1 concentration in children's blood and their mothers. This is similar to the study of Wangikar et al. (2005), who stated that the presence of AFB1 in cord blood samples from pregnant women suggested fetal exposure through trans-placental transfer of the mycotoxin.

When grouping the children according to their type of feeding whether breastfed (partially or wholly) or non breastfed (artificially fed, cow's milk fed or fully weaned), the present study found that AFB1 level was significantly positive in non breastfed than in breastfed children (Table 2). We can hypothesize that the increase in aflatoxin level in non - breastfed children might be due to the possible effect of breast milk on the intestinal absorption of aflatoxin or it affects the metabolism of AFB1 to active metabolites once ingested. However, this hypothesis is not supported by experimental data so far to our knowledge. Gong et al. (2003), suggested that weaning status, rather than age, is the major determinant of aflatoxin exposure level in young children. The lower aflatoxin levels associated with breast feeding almost certainly reflect lower levels of aflatoxin in breast milk than weaning and family foods and even lower levels of exposure might be expected in wholly breastfed infants.

The result of the present study was in accordance to the finding by Gong et al. (2004) who found that the change from partial breast-feeding to complete weaning correlated with the largest increase in 
aflatoxin level, possibly reflecting the increasing proportion of total food consumption coming from the weaning and family foods as the child gets older. Also, this is in agreement to Rastogi et al. (2004) who mentioned that the consumption of milk and milk products by human population is quite high, particularly among infants and young children thereby increasing the risk of exposure to AFB1. Since milk and milk products are a major source for introducing aflatoxins in the human diet, the occurrence of AFB1 in this product is of concern.

A striking association between aflatoxin and impaired growth in children has been previously reported by Gong et al. (2002). Turner et al. (2003) have previously demonstrated that high levels of aflatoxin exposure in childhood were associated with growth deterioration in infants and young children from West Africa. These observations are in agreement with growth im- pairment associated with aflatoxin exposure in animals (Williams et al., 2004).

In the present study, HAZ but not WAZ score was significantly lower in aflatoxin positive than in aflatoxin negative children. HAZ score showed a significant negative correlation with AFB1 level (Table 3). This was in accordance to the results of Gong et al. (2004). To date the mechanism of growth faltering is unknown. It may be a consequence of inhibition of protein synthesis, caused by aflatoxin-induced disruption to RNA synthesis. Alternatively, it has been suggested experimentally that an intestinal mal-absorption may occur following aflatoxin exposure (Turner et al., 2007).

In conclusion, this study suggests that breast feeding results in lower aflatoxin exposure and that there is a strong association between aflatoxin exposure and impaired growth. 
Table (1): Socio-demographic Data of the Studied AFB1 Positive and Negative Children and Their Mothers.

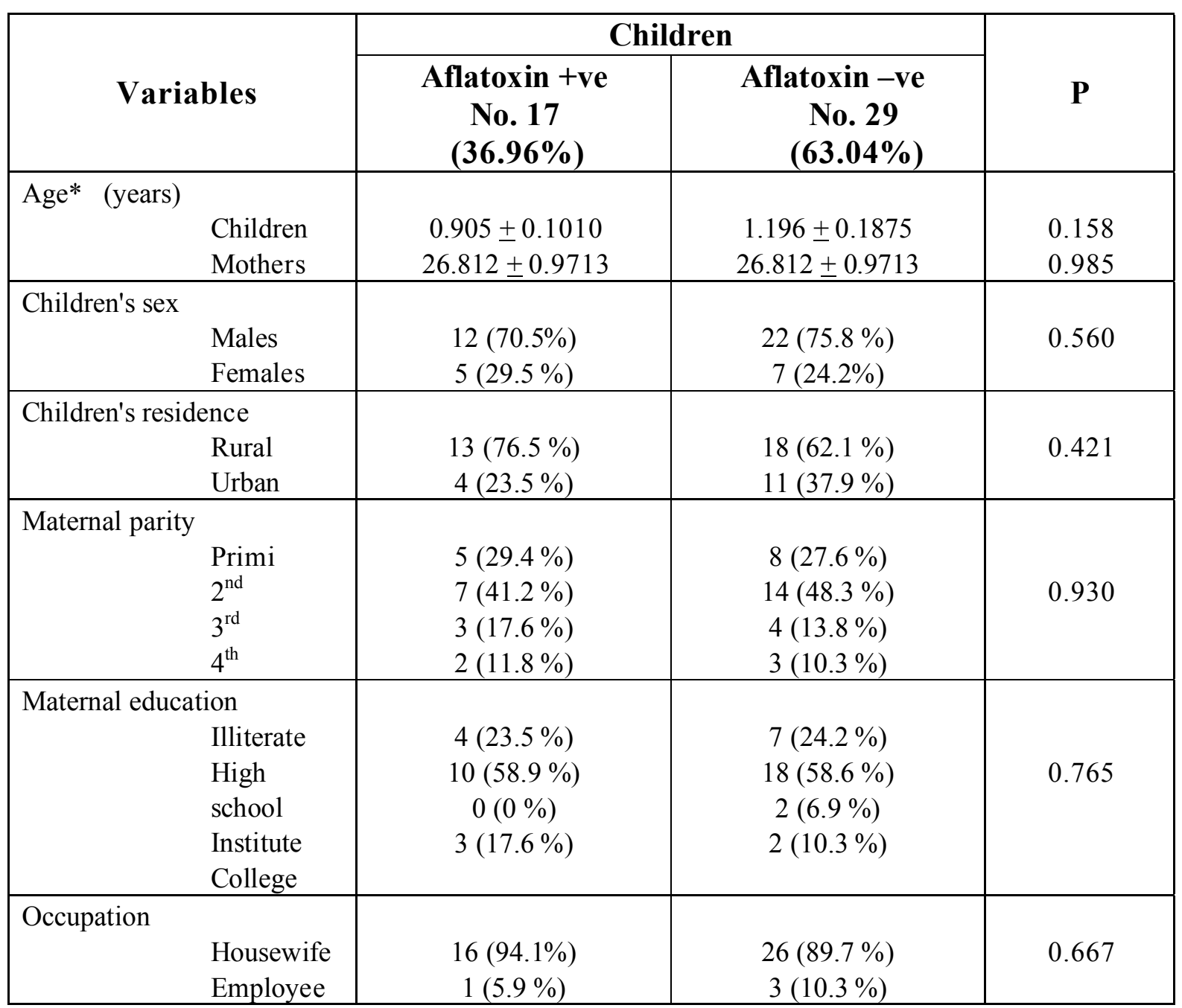

$+v e=$ Positive; $-v e=$ Negative. All data are presented as number $($ percentage $)=$ No. $(\%)$; except age ${ }^{*}$ presented as mean \pm SE. $p<0.05$ is signific a $t$. 
Table (2): Feeding and Growth Measurements of the Studied AFB1 Positive and Negative Children.

\begin{tabular}{|c|c|c|c|}
\hline \multirow{2}{*}{ Variables } & \multicolumn{2}{|c|}{ Children } & \multirow{2}{*}{$\mathbf{P}$} \\
\hline & Aflatoxin +ve & Aflatoxin-ve & \\
\hline 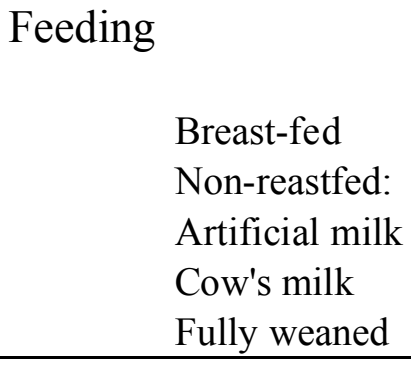 & $\begin{array}{c}3(17.6 \%) \\
11(64.7 \%) \\
2(11.8 \%) \\
1(5.9 \%)\end{array}$ & $\begin{array}{c}14(48.3 \%) \\
10(34.5 \%) \\
0(0 \%) \\
5(17.2 \%)\end{array}$ & $0.034 *$ \\
\hline WAZ & $-0.535 \pm 1.944$ & $0.983 \pm 1.546$ & 0.422 \\
\hline HAZ & $-0.95(-1.89--0.33)$ & $\begin{array}{c}-0.19(-0.605-- \\
0.665)\end{array}$ & $0.001 * *$ \\
\hline
\end{tabular}

Feeding is presented as number (percentage) $=$ No. $(\%)$. WAZ is presented as mean \pm SD while HAZ is presented as median (IQR). $\mathrm{p}<0.05$ is signific a $\mathrm{n}$.

Table (3): Correlation between Different Parameters with AFB1 Level in Studied Mothers and Children.

\begin{tabular}{|l|c|c|}
\hline \multirow{2}{*}{} & \multicolumn{2}{|c|}{ Children level } \\
\cline { 2 - 3 } & $\mathbf{R}$ & $\mathbf{P}$ \\
\hline Mother level & 0.881 & $0.0001^{* *}$ \\
\hline WAZ & -0.199 & 0.185 \\
\hline HAZ & -0.460 & $0.001^{* *}$ \\
\hline
\end{tabular}

$\mathrm{p}<0.05$ is significant 


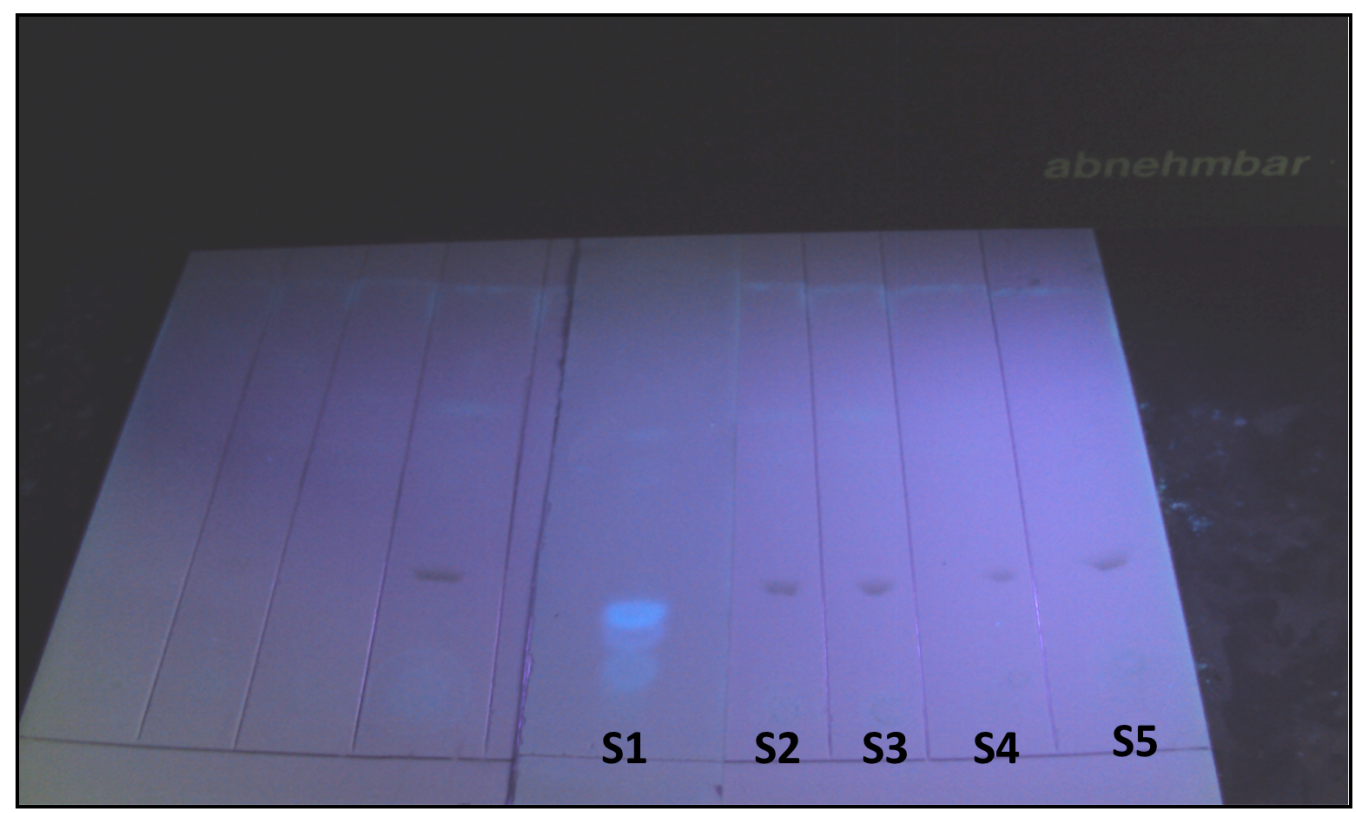

Chart (1): TLC Plate of extract residue of AFB1 in children blood samples against standard AFB1. S1: AFB1 Standard.

S2- S5: Children blood samples (AFB1 Negative).

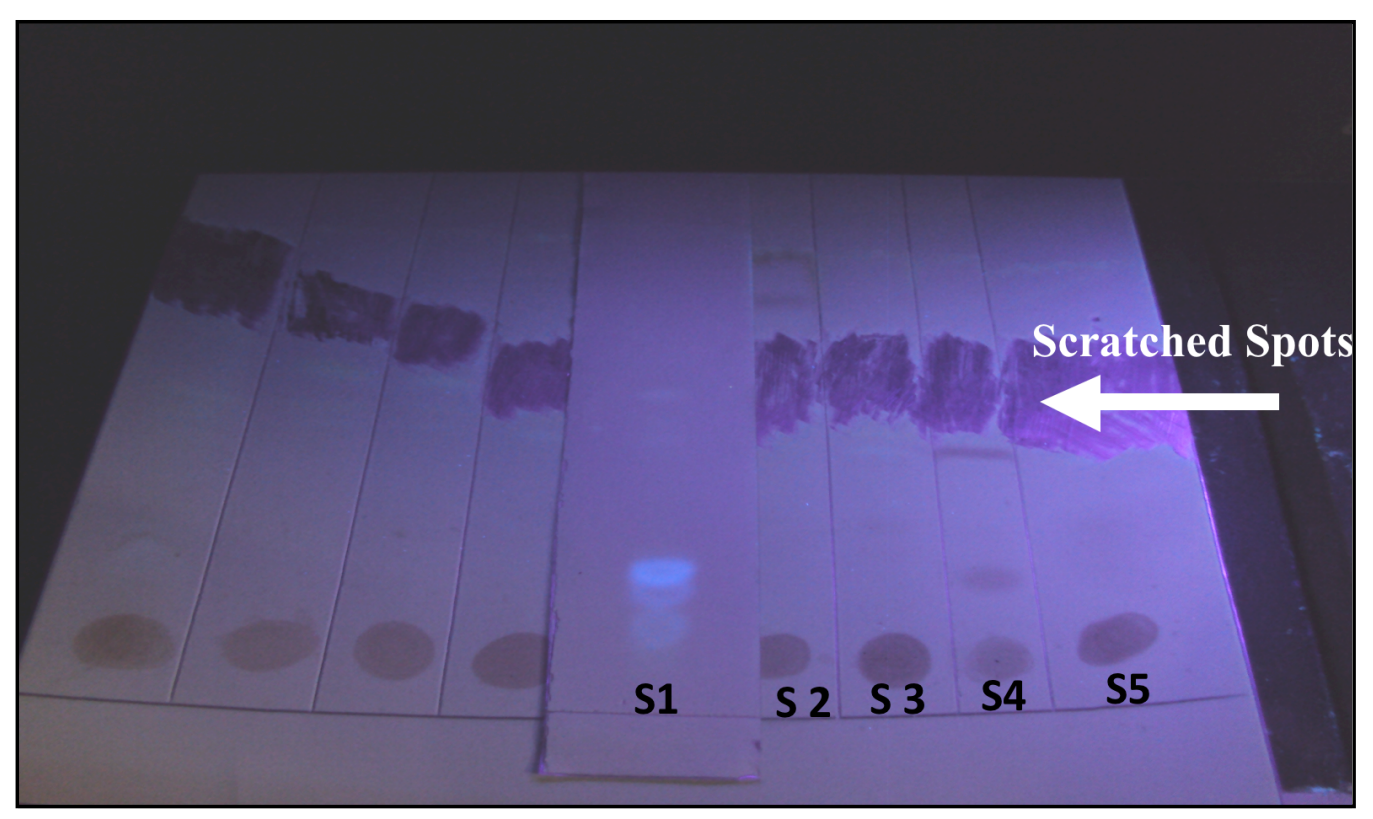

Chart (2): TLC Plate of extract residue showing quantitative analysis of AFB1 (as shown by scratching of the spots) in children blood samples against standard AFB1.

S1: AFB1 standard.

S2 - S5: Children blood samples (AFB1 Positive). 


\section{REFERENCES}

Abdelhamid, A. M. (1981) : Mycotoxine in österreichischen Futtermitteln. Diss. Boku. Univ., Wien.

Abdelhamid, A. M.; El-Mansoury, A. M.; Osman, A. I. and El-Azab, S. M. (1999) : "Mycotoxins as causative for human food poisoning under Egyptian conditions". J. Agric. Sci., Mansoura Univ., 24: 2751 - 2757.

Abdulrazzaq, Y. M.; Osman, N.; Yousif, Z. M. and Trad, O. (2004) : "Morbidity in neonates of mothers who have ingested aflatoxins". Ann. Trop. Paediatr., 24:145151.

Averkieva, O. (2009) : "Mycotoxins in grains harvested in 2008: Wheat Mycotoxins- contamination LC- MS/MS Czech Repub. Microsoft". Mycotoxins Technical Article, Engormix. Com., 10.

Denning, D. W.; Allen, R.; Wilkinson, A. P. and Morgan, M. R. (1990) : " Transplacental transfer of aflatoxin in humans". Carcinogenesis, 11: 1033-1035.

DeVries, H. R.; Maxwell, S. M. and Hendrickse, R. G. (1989) : "Foetal and neonatal exposure to aflatoxins". Acta Paediatr. Scand., 78: 373-378.

Duncan, H. E. and Hagler, W. M.
(2008) : "Aflatoxins and other mycotoxins". Mycotoxins Technical Articles, Engormix. Com., 8.

El-Nezami, H. S.; Nicoletti, G.; Neal, G. E.; Donahu, D. C. and Ahokas, J. T. (1995) : "Aflatoxin M1 in human breast milk samples from Victoria, Austria and Thailand". Food Chemical Toxicology, 33: 173-179.

Eppley, R. M. (1968) : "Screening method for zearalenone, aflatoxin and ochratoxin". J. AOAC., 51 (1): 74 - 78.

Gong, Y. Y.; Cardwell, K.; Hounsa, A.; Egal, S.; Turner, P. C. and Hall, A. J. (2002) : "Dietary aflatoxin exposure and impaired growth in young children from Benin and Togo: Cross sectional study". British Medical Journal, 325: 20 -21.

Gong, Y. Y.; Egal, S.; Hounsa, A.; Turner, P. C.; Hall, A. J.; Cardwell, K. F. and Wild, C. P. (2003) : "Determinants of aflatoxin exposure in young children from Benin and Togo, West Africa: the critical role of weaning". International Journal of Epidemiology, 32: 556 - 562.

Gong, Y. Y.; Hounsa, A.; Egal, S.; Turner, P. C.; Sutcliffe, A. E.; Hall, A. J.; Cardwell, K. and Wild, C. P. (2004) : "Postweaning exposure of aflatoxin results in impaired child growth: A longitudinal study in Benin, West Africa". Environmen- 
tal Health Perspectives, 112(13): 1334-1338.

Herman, T. and Trigo- Stockli, D. (2008) : "Mycotoxins in feed grains and ingredients". Mycotoxins Technical Articles, Engormix. Com., 12.

Hsieh, L. L. and Hsieh, T. T. (1993) : "Detection of aflatoxin B1-DNA adducts in human placenta and cord blood". Cancer Res., 53: 1278-1280.

Jonsyn, F. E.; Maxwell, S. M. and Hendrickse, R. G. (1995) : "Human fetal exposure to ochratoxin A and aflatoxins". Ann. Trop. Paediatr., 15: 3-9.

Kamkar, A. (2005) : "A study on the occurrence of aflatoxinM1 in raw milk produced in Sarab city of Iran". Food Control, 16: 593 - 599 .

Kihara, T.; Matsuo, T.; Sakamoto, M.; Yasuda, Y.; Yamamoyo, Y. and Tanimura, T. (2000) : "Effects of prenatal aflatoxin B1 exposure on behaviors of rat offspring". Toxicological Sciences, 53 : 392 399.

Massey, T. E.; Steward, R. K.; Daniel, J. M. and Ling, L. (1995) : "Biochemical and molecular aspects of mammalian susceptibility to aflatoxin B1 carcinogenicity". Proceedings of the Society for Experimental Biology and Medicine, 208 : 213 227.
Maxwell, S. M.; Familusi, J. B.; Sodeinde, O.; Chan, M. C. and Hendrickse, R. G. (1994) : "Detection of naphthols and aflatoxins in Nigerian cord blood". Ann. Trop. Paediatr., 14: 3-5.

Montesano, R.; Hainaut, P. and Wild, C. P. (1997) : "Hepatocellular carcinoma: from gene to public health". J. Natl. Cancer Inst., 89: 1844-1851.

Rastogi, S.; Dwivedi, P. D.; Khanna, S. K. and Das, M. (2004) : "Detection of aflatoxin M1 contamination in milk and infant milk products from Indian markets by ELISA". Food Control, 15 : 287 290.

Sadeghi, N.; Oveisi, M. R.; Jannat, B.; Hajimahmoodi, M.; Bonyani, $H$. and Jannat, F. (2009) : "Incidence of aflatoxin M1 in human breast milk in Tehran, Iran". Food Control, 20: 75-78.

Trail, F.; Mahanthi, N. and Linz, J. (1995) : "Molecular biology of aflatoxin biosynthesis". Microbiol. Reading, 141 (4): 755-765.

Turner, P. C.; Collinson, A. C.; Cheung, Y. B.; Gong, Y. Y.; Hall, A. J.; Prentice, A. M. and Wild, C. P. (2007) : "Aflatoxin exposure in utero causes growth faltering in Gambian infants". International Journal of Epidemiology, 36: 1119-1125. 
Turner, P. C.; Moore, S. E.; Hall, A. J.; Prentice, A. M. and Wild, C. P. (2003) : "Modification of immune function through exposure to dietary aflatoxin in Gambian children". Environmental Health Perspectives, 111: 217-220.

Wangikar, P. B.; Dwivedi, A. P.; Sinha, A. N.; Sharma, A. K. and Telang, A. G. (2005) : "Effects of aflatoxin B1 on embryo fetal development in rabbits". Food and Chemical Toxicology, 43: 607615.

Williams, J. H.; Philips, T. D.; Jolly, P.
E.; Stiles, J. K.; Jolly, C. M. and Aggarwal, D. (2004) : "Human aflatoxicosis in developing countries: a review of toxicology, exposure, potential health consequences and interventions". Am. J. Clin. Nutr., 80: 1106 - 1122.

Zarba, A.; Wild, C. P.; Hall, A. J.; Montesano, R.; Hudson, G. J. and Groopman J. D. (1992) : "Aflatoxin M1 in human breast milk from the Gambia, West Africa, quantified by combined monoclonal antibody immunoaffinity chromatography and HPLC". Carcinogenesis, 13 : 891-894. 


\section{مستوى الأفلاتوكسين با وعلاقته بغذاء ونهو الأطفال}

$$
\text { المشتركون فى البحث }
$$

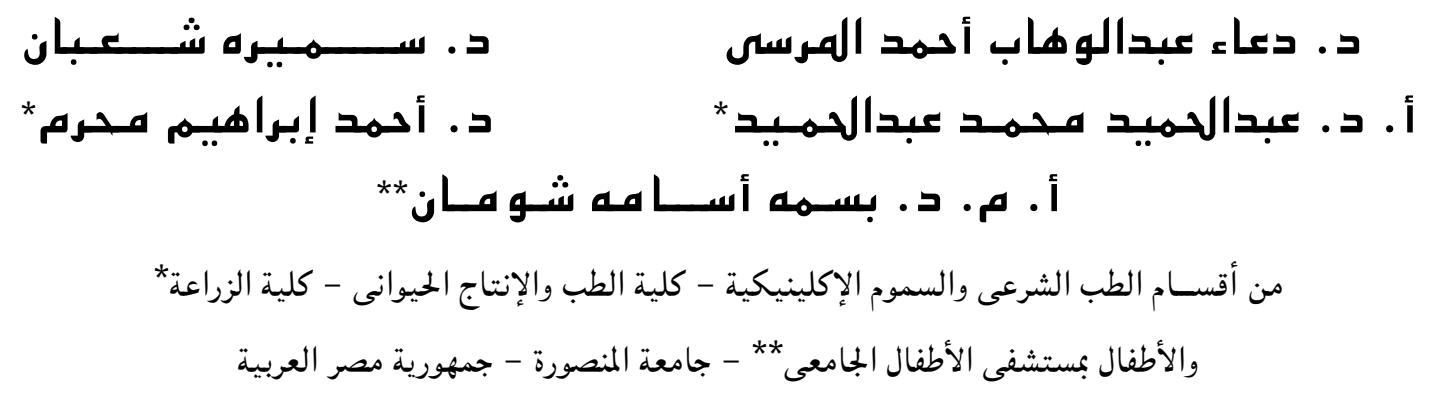

الأفلاتوكسين هى مجموعة من السموم التى يتـم إنتاجها فى الغذاء وتؤدى إلى الإصابة بأمراض الكبد السرطانية وغيرها من السرطانات الأخرى، ويهدف هذا البحث إلى دراسة تأثيـ العوامل الاجتماعيـة والرضاعة الطبيعية والصناعية والفطام على نسبة الأفلاتوكسين فى دم الأطفال وتأثيره على نموهم. وقد تمت الدراسة على آح من الأطفال المترددين على مستشفى الأطفال الجامعى مع أمهاتهم، وقد تم سحب ه مللم من الدم من كل طفل ووالدته بعد أخذ موافقة كتابية منهم، وتم تحليل الدم بإستخدام تحليل الكروماتوجرافى رقيق الطبقات كيفياً وكمياً، وقد

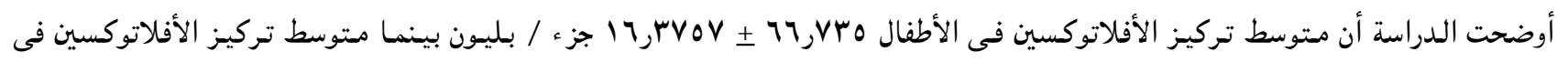

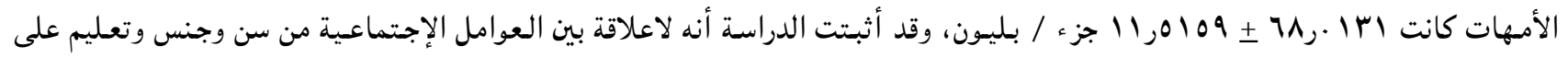
معـدل الأفلاتوكسين، كما أوضحت الدراسـة أن نسبة الأفلاتوكسين كانت أعلى فى الأطفــال الذين تعـتمد تغذيتهـــم على الألبــان الصـناعية

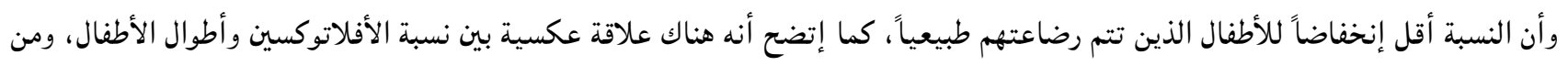
هذه الدراسة يـكن أن نستخلص أن الرضاعة الطبيعية تقلل من نسب الأفلاتوكسين وأن الأفلاتوكسين يؤثر على نمو الأطفال من حيث معدل أطوالهم. 